\title{
A Institucionalização do Atendimento aos Menores - O SAM
}

\section{Institutionalization of Assistance to Minors - SAM}

Resumo: O presente artigo objetiva apresentar a arquitetura do Serviço de Assistência a Menores - SAM, criado em 1941 pelo governo federal para sistematizar, fiscalizar, regulamentar as verbas orçamentárias destinadas à Assistência Social e para ser um orientador técnico e pedagógico das instituições oficiais e privadas de atendimento ao chamado menor desvalido e delinquente. Era um órgão burocrático e técnico que atendia às reivindicações da sociedade e à política de controle social instituída no país. A partir de uma micro-análise de um corpus documental variado como: jornais, legislações, livro-denúncia e os documentos produzidos em uma Comissão Parlamentar de Inquérito, em 1956, criada para investigar denúncias a respeito do SAM, foi possível analisar suas estruturas administrativa e de trabalho, juntamente com a burocracia em torno do atendimento ao menor, durante o período da primeira experiência democrática, foi possível perceber os avanços e os problemas em relação ao atendimento aos menores.

Palavras-chaves: Serviço de Atendimento a Menores. Políticas Públicas. Controle Social.

Abstract: This article aims to present the architecture of the Assistance to Minors Service - SAM, created in 1941 by the federal government to systematize, supervise and regulate budgetary funds destined to Social Assistance and to be a technical and pedagogical advisor for official and private care institutions the so-called underprivileged and delinquent minor. It was a bureaucratic and technical body that met the demands of society and the social control policy

\footnotetext{
* Doutora em História pela UFRRJ - Universidade Federal Rural do Rio de Janeiro. Atualmente é professora I- Ensino Médio - ministrando aulas de História e Sociologia - Secretaria de Estado e Educação do Rio de Janeiro-RJ. Mediadora Presencial da Graduação em História Licenciatura - UNIRIO/CECIERJ nas disciplinas História e Sociologia e História e Antropologia.
} 
instituted in the country. From a micro-analysis of a varied documentary corpus such as: newspapers, legislation, denunciation book and documents produced by a Parliamentary Commission of Inquiry, in 1956, created to investigate complaints about SAM, it was possible to analyze its administrative structures and work, together with the bureaucracy surrounding the care of minors, during the period of the first democratic experience, it was possible to notice the advances and problems in relation to the care of minors.

Keywords: Child Support Service. Public policy. Social Control.

\section{1- Introdução}

No Brasil, o atendimento aos desvalidos, durante muito tempo, foi uma política no Estado, assim dizendo, "as crianças nascidas em situação de pobreza e/ou em famílias com dificuldades de criarem seus filhos tinham um destino quase certo quando buscavam apoio do Estado: o de serem encaminhadas para instituições como se fossem órfãs ou abandonadas" (RIZZINI; RIZZINI, 2004, p. 13). A partir de uma análise documental, como: jornais, processos administrativos e em bibliografias especializadas, observamos que as crianças e adolescentes em situação de risco e vulnerabilidade social eram encaminhadas pelo Estado, no século XIX e primeiras décadas do século XX, às instituições particulares de características asilares para o atendimento e para suprimento das necessidades materiais desses indivíduos.

O Brasil sempre carregou, desde o período colonial, a característica da assistência social concentrada nas ações de instituições filantrópicas leigas e religiosas, principalmente da Irmandade da Misericórdia (SANGLARD, 2005, p. 64), que buscavam oferecer auxílio material e espiritual aos pobres, órfãos, enfermos, alienados e delinquentes. O Estado possuía participação limitada nessa área, concedendo algum tipo de subvenção a essas instituições de caráter privado ou intervindo em situações de calamidade pública, como em épocas de epidemia (RIZZINI, 2008).

Essas ações, um tanto quanto pontuais, receberam algumas críticas de estudiosos do assunto da época, atribuindo a característica de "Caridade Oficial do Estado" (PILOTTI; RIZZINI, 2009, p. 240) denunciando o modo como o 
Estado tratava a assistência pública, assinalada por ações descontinuadas, desorganizadas e de breve duração com resultados frívolos, porquanto não havia política de Estado sobre o assunto. Segundo Pilotti e Rizzini os trabalhos de assistência eram realizados parceladamente, sem o rigor técnico e cooperação eficaz, "sem a organização inteligente dos auxílios recíprocos e dos resultados compensadores" (Idem. P. 240).

Algumas ações públicas de proteção às crianças e adolescentes foram implementadas pelo Estado, antes de 1930, como as Escolas Premonitórias, a Colônia Correcional de Dois Rios, os Patronatos Agrícolas e em 1927 com o Código de Menores, conhecido como Código Melo Matos. Contudo, devido a uma falta de organização à assistência de crianças e adolescentes que necessitavam do Estado, foi elaborado, primeiro no campo das ideias e depois de forma material, um órgão que concentrasse as ações de assistência ao menor $^{1}$, primando pela eficiência, organização e ações continuadas de apoio aos menores.

Foi criado, neste contexto, em 1940, o Departamento de Nacional da Criança (DNCr), um órgão de "coordenação de todas as atividades nacionais relativas à proteção à maternidade, à infância e à adolescência ${ }^{2 "}$ de grande importância à época. Foi idealizado a partir de concepções das ciências médicas, higiênicas e de puericultura e estava vinculado ao Ministério da Educação e Saúde. Por conseguinte, surgiu o Serviço de Assistência ao Menor - SAM. 3 Veremos um pouco mais da criação e função desse órgão.

Portanto, pretende-se com esse artigo apresentar a arquitetura do Serviço de Assistência a Menores, criado em 1941 pelo governo federal. Apresentando e analisando suas estruturas administrativa e de trabalho, juntamente com a

\footnotetext{
${ }^{1}$ É importante informar ao leitor que utilizei a terminologia "menor" encontrada nas fontes documentais desta pesquisa, contudo cabe salientar que não é o meu entendimento sobre as crianças e adolescentes. Para melhor entendimento escolhemos trabalhar com essa categoria de forma destacada para evitar uma possível confusão do leitor entre fontes e análises.

2 BRASIL, Decreto-Lei ${ }^{\circ}$ 2.024, de 17 de fevereiro de 1940. Fixa as bases da organização da proteção à maternidade, à infância e à adolescência em todo o País. Disponível em: https://www2.camara.leg.br/legin/fed/declei/1940-1949/decreto-lei-2024-17-fevereiro-1940411934-publicacaooriginal-1-pe.html Acesso 22/09/2020

$3 \mathrm{O}$ primeiro órgão nacional de regulação é o departamento nacional da criança, conforme rege seu artigo $5^{\circ}$ (art. $5^{\circ}$ será o departamento nacional da criança o supremo órgão de coordenação de todas as atividades nacionais relativas à proteção à maternidade, à infância e à adolescência. BRASIL, Decreto-Lei n ${ }^{0}$ 2.024, de 17 de fevereiro de 1940. Contudo, o Serviço de Assistência a Menores (SAM) pode ser considerado o primeiro órgão nacional de atendimento ao menor e o que teve mais amplitude de ação.
} 
burocracia em torno do atendimento ao menor, durante o período da primeira experiência democrática.

O Serviço de Assistência a Menores (SAM) foi criado para sistematizar, fiscalizar, regulamentar as verbas orçamentárias destinadas à Assistência Social e para ser um orientador técnico e pedagógico das instituições oficiais e privadas de atendimento ao menor desvalido e delinquente. Era um órgão burocrático e técnico que atendia às reivindicações da sociedade e à política de controle social instituída no país.

Contudo, era um órgão que apresentava problemas de organização, procedimentos e uma burocracia insulada ${ }^{4}$ que favoreceu a atuação irregular de diversos agentes públicos. Nas pesquisas realizadas sobre o SAM, encontrei o corpus documental utilizado, sendo eles: jornais, legislações, o livro-denúncia Sangue, Corrupção e Vergonha, escrito por Paulo Nogueira Filho, ex-Deputado Federal e ex-Diretor do SAM e os documentos produzidos em uma Comissão Parlamentar de Inquérito, criada para investigar as denúncias de Paulo Nogueira Filho a respeito do Serviço de Assistência a Menores. Essas fontes foram importantes para analisar o serviço de atendimento ao menor, assim como os problemas deste.

\section{2- Percurso do Atendimento a Menores: das Escolas Premonitórias e Correcionais ao Serviço de Assistência a Menores - (SAM)}

A Escola Quinze de Novembro foi fundada em 1899 no Ministério da Justiça e Negócios Interiores (MJNI) e possuía o objetivo principal de servir de internato para os menores recolhidos pela polícia do Rio de Janeiro. Após sua criação passou a se chamar Escola Correcional Quinze de Novembro, reforçando o seu caráter punitivo, recebendo menores recolhidos pelo corpo policial da cidade (VIANNA, 1999a).

\footnotetext{
4 Conceito cunhado por Edson Nunes, que analisou que durante o primeiro governo de Vargas surgiu na administração direta órgãos e procedimentos que pretendiam isolar os funcionários públicos das possíveis ingerências externas. Mas que conjuntamente com outras gramáticas também estudadas pelo autor, demonstraram que começou uma articulação mais complexa para corromper o sistema. (NUNES, 1997)
} 
As casas correcionais passaram por uma reformulação em 1902, através da Lei $n^{0} 947$ de 29 de dezembro de 1902, com a finalidade de reabilitar a partir do trabalho e da instrução, os mendigos válidos, vagabundos ou vadios, capoeiras e menores viciosos 5 que fossem encontrados e julgados no Distrito Federal ${ }^{6}$. No artigo $7^{\circ}$, a lei ampliava a categoria de indivíduos a serem recolhidos à essas casas correcionais, como:

I. Os menores de 14 annos, maiores de 9, inculpados criminalmente que forem julgados como tendo agido sem discernimento, nos termos dos arts. 30 e 49 do Codigo Penal. II. Os menores abandonados de 14 annos, maiores de 9 que, por serem orphãos ou por negligencia ou vicios, ou enfermidades dos paes, tutores, parentes ou pessoas em cujo poder, guarda ou companhia, vivam, ou por outras causas, forem encontrados habitualmente sós na via pública, entregues a si mesmos e privados de educação. ${ }^{7}$

Com a promulgação da Lei 947/1902, foi necessária a reformulação da antiga Escola Correcional Quinze de Novembro. Em 1903, recebeu um novo nome, passando para Escola Premonitória Quinze de Novembro e uma nova regulamentação, através do decreto $\mathrm{n}^{0} 4.780$, de 2 de março, objetivando "dar educação física, profissional e moral aos menores abandonados e recolhidos ao estabelecimento por ordem das autoridades competentes". ${ }^{8}$ O nome da instituição estava relacionado a nova característica que esta passava a ter, a de prevenir que os menores abandonados se transformassem em infratores no futuro (VIANNA, 1999a, p. 63).

A transformação ocorrida em 1903 possuía o intuito de modernizar o atendimento a esses menores. Visto que os intelectuais e os técnicos do Poder Judiciário do período procuravam se espelhar em outras sociedades, como a europeia e a norte-americana, tratadas no decreto como "povos cultos", no que diz respeito ao atendimento a esses indivíduos. ${ }^{9}$

\footnotetext{
5 Terminologia da época. BRASIL, Decreto $\mathrm{n}^{0} 4.780$ de 02 de março de 1903. Approva o regulamento para a Escola Correccional Quinze de Novembro. Disponível em: https://www2.camara.leg.br/legin/fed/decret/1900-1909/decreto-4780-2-marco-1903-515922publicacaooriginal-1-pe.html Acesso 25/01/2019

${ }^{6}$ BRASIL. Lei $\mathrm{n}^{0} 947$ de 29 de dezembro de 1902 - Reforma o serviço policial no Districto Federal. Disponível em: https://www2.camara.leg.br/legin/fed/lei/1900-1909/lei-947-29dezembro-1902-584264-republicacao-107075-pl.html acesso em: 25/o1/2019 7 Idem.
}

8 BRASIL. Decreto $\mathrm{n}^{\mathrm{o}} 4.780$ de 02 de março de 1903. Disponível em: <https://www2.camara.leg.br/legin/fed/decret/1900-1909/decreto-4780-2-marco-1903515922-publicacaooriginal-1-pe.html> Acesso em: 25/01/2019 9 Idem. 
A ideia de que se os menores estivessem em um lugar que fosse similar a um ambiente familiar, em que estudassem e aprendessem um ofício, trazendo melhores resultados no desenvolvimento destes e da sociedade ${ }^{10}$ foi uma motivação para a nova regulamentação da Escola Correcional. Percebemos então uma mudança na concepção da assistência, destinada a partir daquele momento, a prevenir as desordens e recuperar os desviantes, a partir do pensamento higienista ${ }^{11}$ presente no início do séc. XX.

Outras casas premonitórias e correcionais surgiram, seguindo o mesmo intuito da Quinze de Novembro, inclusive em outros Estados. Muitas dessas casas erigidas nas primeiras décadas do século XX possuíam características repressivas, como a Casa de Detenção do Distrito Federal e a Colônia Correcional de Dois Rios.

Aos chefes de polícia e delegados auxiliares no Distrito Federal, desde 1899, competia combater os crimes de vadiagem, mendicância, capoeiragem, embriaguez, jogos de azar, loterias e rifas não autorizadas por lei, movendo ações contra tais crimes, controlando as fases do julgamento, assim como executando a sentença (VIANNA, 1999a, p. 45). Consequentemente a polícia ficava a cargo de controlar a questão do menor, recolhendo e instaurando processo junto ao poder judiciário e posteriormente executando a decisão judicial.

Especificamente no Distrito Federal, o recolhimento de menores ficava sob a responsabilidade das delegacias distritais ou do Corpo de Segurança Pública, que possuíam a finalidade de patrulhar a cidade. Após recolher a criança ou o adolescente cabia à Secretaria, na figura do chefe de Polícia, escolher para qual instituição os menores seriam internados. $O$ juiz de órfãos também participava desse processo, no entanto, em escala ínfima perto dos

\footnotetext{
${ }^{10}$ Idem.

${ }^{11} \mathrm{O}$ higienismo brasileiro pode ser definido como o estabelecimento de normas e hábitos para conservar e aprimorar a saúde coletiva e individual. Contudo, foi um movimento complexo visto sua generalidade difusa e heterogênea, tanto no âmbito político quanto no científico. $\mathrm{O}$ "movimento higienista" era altamente heterogêneo sob o ponto de vista teórico (nos seus fundamentos biológicos e raciais) e ideológico (liberalismo e antiliberalismo). ver: HOCHMAN, Gilberto. A Era do Saneamento: As bases da política de Saúde Pública no Brasil, [s.l.: s.n.], 2012; PILOTTI; RIZZINI. A arte de governar crianças; JUNIOR, Edivaldo Góis, Movimento Higienista e o Processo Civilizador: p. 9 - 15 .
} 
chefes de polícia, até a década de 1920, que em sua maioria realizavam essas ações (VIANNA, 1999b, p. 72).

A partir da década de 1920 alterações importantes ocorreram na questão dos menores no Brasil, foi aprovado o regulamento da assistência e proteção aos menores abandonados e delinquentes, através da aprovação do Decreto $\mathrm{n}^{0}$ 16.272, em 20 de dezembro de 1923, e foi criado um Juizado de Menores, para atender especialmente o Distrito Federal. Diziam os artigos 37 e 38 desse Decreto:

\begin{abstract}
Art. 37. É creado no Districto Federal um Juizo de Menores, para assistencia, protecção, defesa, processo e julgamento dos menores abandonados e delinquentes.

Art. 38. Ao juiz de menores compete:

I, processar e julgar o abandono de menores, nos termos deste regulamento, e os crimes ou contravenções por elles perpetrados; II, inquirir e examinar o estado physico, mental e moral dos menores, que comparecerem a juizo, e, ao mesmo tempo, a situação social, moral e economica dos paes, tutores e responsaveis por sua guarda; III, ordenar as medidas concernentes ao tratamento, collocação, guarda, vigilancia e educação dos menores abandonados ou delinquentes; IV, decretar a suspensão ou a perda do patrio poder ou a destituição da tutela, e nomear tutores; V, praticar todos os actos de jurisdicção voluntaria tendentes á protecção e assistencia aos menores; VI, impôr e executar as multas a que se refere este regulamento; VII, fiscalizar os estabelecimentos de preservação e de reforma, e quaesquer outros em que se achem menores sob sua jurisdicção, tomando as providencias que lhe parecerem necessarias; VIII, exercer as demais attribuições pertencentes aos juizes de direito e comprehensivas na sua jurisdicção privativa; IX, cumprir e fazer cumprir as disposições deste regulamento, applicando nos casos omissos as disposições de outras leis, que forem applicaveis ás causas civeis e criminaes da sua competencia; $X$, organizar uma estatistica annual e um relatorio documentado do movimento do juizo, que remetterá ao Ministro da Justiça. ${ }^{12}$
\end{abstract}

Com as atribuições do recém-criado Juizado na capital federal, foi necessária a criação de um lugar para o abrigo temporário dos menores, até a

\footnotetext{
${ }^{12}$ BRASIL. Decreto $\mathrm{n}^{\circ}$ 16.272, de 20 de dezembro de 1923. Aprova o regulamento da assistência e proteção aos menores abandonados e delinquentes. Coleção das leis da República dos Estados Unidos do Brasil. Rio de Janeiro, v. 3, parte 1, p. 363-383, 1923a. Coloque o link: https://www2.camara.leg.br/legin/fed/decret/1920-1929/decreto-16272-20-dezembro-1923517646-publicacaooriginal-1pe.html\#: :text=4.242\%2C\%2Ode\%205\%20de\%20janeiro,da\%2OJusti\%C3\%A7a\%20e\%20Neg ocios\%20Interiores. Acesso 27/01/2019
} 
realização da triagem. Deste modo, o referido decreto criou, também, o Abrigo de Menores:

Art. 62. Subordinado ao juizo de menores, haverá um Abrigo, destinado a receber provisoriamente, até que tenham destino definitivo, os menores abandonados e delinquentes.

Art. 63. O Abrigo compor-se-ha de duas divisões, uma masculina e outra feminina; ambas subdividir-se-hão em secções de abandonados e delinquentes; e os menores serão distribuidos em turmas, conforme o motivo do recolhimento, sua idade e gráo de perversão.

Art. 64. Os menores se occuparão em exercicios de leitura, escripta e contas, lições de cousas e desenho, em trabalhos manuaes, gymnastica e jogos desportivos.

Art. 65. Qualquer menor, que de entrada no Abrigo, será recolhido a um pavilhão de observação, com aposentos de isolamento, depois de inscripto na secretaria, photographado, submettido á identificação, e examinado pelo medico e por um professor; e ahi será conservado em observação durante o tempo necessário. ${ }^{13}$

A partir desse decreto, a Quinze de Novembro foi dividida em duas sessões, "reforma" e "preservação". A seção de preservação foi destinada a receber os menores do sexo masculino, entre 14 (quatorze) e 18 (dezoito) anos, julgados e enviados para internação pelo juiz de menores, com a intenção de serem reabilitados pelo trabalho, pela educação e pela instrução. A sessão de reforma era designada aos menores criminosos e contraventores. As duas sessões funcionariam em prédios distintos, com uma mesma administração. ${ }^{14}$

Entretanto não foi possível implantar a sessão de reforma, visto que as obras de construção do edifício onde seria instalada foram suspensas por ordem de Afonso Pena Júnior, então Ministro da Justiça, que justificou tal ato por acreditar ser inaceitável que os menores abandonados ficassem próximos dos criminosos e contraventores (VIANNA, 1999a).

Três anos depois, em 1926, foi aprovado um novo regulamento para a sessão de reforma da Quinze de Novembro, chamada Escola João Luiz Alves, a qual foi "instalada em terreno pertencente à União, na Ilha do Governador, onde anteriormente funcionara a Colônia de Alienados" (PESSOA, 2018).

13 Idem.

14 Idem. 
A década de 1920 foi importante, pois representou uma mudança de conduta do Estado, que começou a realizar políticas públicas de caráter social em prejuízo das ações policialescas existentes até aquele momento.

Todavia, ainda que o Estado estivesse aprimorando sua forma de atender os menores em situação de risco e vulnerabilidade social, havia muita desorganização e uma heterogeneidade de ações, analisando que as unidades federativas possuíam autonomia de formular e determinar as ações em relação aos menores.

No Jornal do Commercio Edição da Tarde noticiou-se em 10 de novembro de 1914, que foram recenseados, sob encomenda do prefeito do Rio de Janeiro, General Bento Ribeiro, mais de 500 estabelecimentos, em sua maioria privados, dirigidos à infância, à velhice, à mulher, aos estrangeiros e à mendicidade profissional. ${ }^{15}$

As análises do período demonstravam o desejo por parte de intelectuais como Ataulpho de Paiva, Moncorvo Filho e Franco Vaz, de que houvesse uma ação mais direta por parte do Estado, de maneira a promover a centralização e a unissonância dos serviços em um único órgão que uniria os trabalhos dos poderes públicos e das iniciativas particulares. Essas ideias eram enaltecidas nas propostas de criação de serviços de assistência pública (PILOTTI; RIZZINI, 2009, p. 236).

O juizado de menores passou a decidir sobre a vida das crianças e adolescentes, fossem eles recolhidos pela polícia ou entregues pela família, em decorrência de problemas com o próprio menor ou problemas na estrutura familiar. Os menores abandonados, normalmente eram encaminhados às instituições públicas existentes e os menores entregues pelas famílias eram enviados para instituições particulares que eram subvencionadas pelo governo.

O Código Civil de 1916 trouxe em seu artigo 395 que os pais perderiam o pátrio poder sobre os filhos se os castigassem imoderadamente, os abandonassem e/ou praticassem atos contrários à moral e aos bons costumes ${ }^{16}$.

15 Jornal do Commercio de 10 de novembro de 1914. Edição da Tarde. Ed. 1560. Fonte: Biblioteca Nacional. Hemeroteca Digital Disponível em: http://memoria.bn.br/DocReader/DocReader.aspx?bib=111988\&pesq=Ataulpho\%20de\%20Pai va\&pasta $=$ ano\%20191 Acessado em: 23/05/2019

${ }^{16}$ BRASIL. LEI No 3.071, de $1^{\circ}$ de janeiro de 1916. Código Civil dos Estados Unidos do Brasil. Disponível em: http://www.planalto.gov.br/ccivil_03/leis/l3071.htm Acesso 22/09/2020 
E a partir da Lei 16.272/1923, um novo conceito de abandono, o que podemos analisar como uma forma de regulamentar a educação dos filhos de famílias, social e economicamente carentes. A referida lei, também, pontuava vários prérequisitos para considerar um menor como "abandonado", elencamos alguns deles: não ter residência fixa; não possuir meios de subsistência; trabalhar em locais ou ofícios proibidos ou contrários à moral e aos bons costumes, vagar pelas ruas ou mendigar. ${ }^{17}$

Podia o Governo Federal, dessa forma, controlar a utilização das verbas públicas, como as subvenções dadas às instituições privadas. Controlando a assistência social através dos atendimentos feitos pelas instituições privadas, o Estado diminuía os gastos públicos com tais ações, mesmo ele subvencionando essas instituições (PILOTTI; RIZZINI, 2009, p. 239). Outro ponto seria as instituições receberem, mais facilmente, as verbas públicas, tão cobiçadas e de difícil acesso.

Com a criação do Juizado de Menores, o juiz passou a determinar a internação das crianças e adolescentes apreendidos ou levados até o juizado, retirando do poder policial essa função. Desse modo o juiz encaminhava o menor para uma das unidades de assistência, pública ou privada, contratada para atender esse indivíduo. Essas instituições privadas que recebiam, do juizado, os menores, eram contratadas a partir de convênios com o Ministério da Justiça, em que recebiam subvenções por essas internações, ou eram contratadas diretamente pelo juizado, mediante pagamento de um valor mensal per capita. ${ }^{18}$

A partir do que foi analisado nas fontes e descrito nos parágrafos anteriores, a reivindicação no período era pela criação de um órgão central que cuidasse da assistência ao menor. A partir de 1930, a assistência ao menor se transformou em uma política de defesa nacional, visto que era preciso formar essa massa jovem para o mercado de trabalho, porquanto, seguindo a linha de pensamentos de autores internacionais da época, não se poderia favorecer demais o menor atendido, pois poderia se criar "uma classe de indivíduos a

${ }_{17}$ Op. Cit. Art. $2^{\circ}$

18 Explicaremos mais à frente o significado de pagamento per capita na seara da assistência Social. 
quem Mário D’Ambrósio chamaria de economicamente passivos" (PILOTTI; RIZZINI, 2009, p. 177), movimentando, consequentemente, a economia.

Outro ponto importante era a ideia do atendimento ao menor auxiliar no afastamento da ameaça comunista, no período (PILOTTI; RIZZINI, 2009, p. 177). Durante uma palestra na Academia Brasileira de Letras, Sabóia Lima, Juiz de Menores, defendia que cuidar da criança fazia parte da "defesa da pátria e da sociedade", uma vez que "a criança é um dos elementos mais disputados pelo comunismo" (LIMA Apud RIZZINI, 2009. p.262). Por conseguinte, assistir a criança necessitada a partir de métodos científicos era observado como um instrumento de defesa nacional e da consciência do elevado valor do país (LIMA Apud RIZZINI, 2009. p.262).

Seguindo a concepção de assistência ao menor que estava se estruturando no período, o Abrigo de Menores do então Distrito Federal passou a chamar-se Instituto Sete de Setembro, especializado para a assistência e cuidado do menor.

O Instituto Sete de Setembro foi regulamentado pelo Decreto ${ }^{0}{ }^{0} 21.518$ de 13 de junho de 1932 e possuía a finalidade de "recolher em depósito, por ordem do Juiz de Menores, até que tenham convincente destino, autorizado pelo mesmo Juiz, os menores abandonados nos termos da lei 19". Nesse abrigo os menores eram avaliados, pelo juiz de menores, pelo diretor, pelo professor, com o objetivo de conhecer o caráter, o grau de instrução e as aptidões. Essa instituição caracterizou-se como provisória, contudo, os menores que eram encaminhados para lá poderiam ficar internados permanentemente. ${ }^{20}$

\section{3- O SAM - Serviço de Assistência a Menores, a grande solução?}

Atendendo a reivindicação da sociedade e a política de controle social instituída no país, em 1941, foi criado o SAM - Serviço de Atendimento a Menores. Getúlio Vargas sancionou o Decreto-lei no 3.799 de 05 (cinco) de

19 BRASIL. Decreto $\mathrm{n}^{0}$ 21.518, de 13 de junho 1932. Aprova o novo regulamento do Instituto Sete de Setembro. Disponível em: https://www2.camara.leg.br/legin/fed/decret/19301939/decreto-21518-13-junho-1932-517487-publicacaooriginal-1-pe.html Acesso 10/o5/2019 ${ }^{20}$ Interessante analisar que, nesse período, diversos países capitalistas passavam por uma intensa crise, em decorrência da quebra da Bolsa de Nova York. O modelo keynesiano, implantado nos Estados Unidos da América, foi adotado por muitos desses países, que assumiram uma postura protecionista, visando o bem-estar de seus cidadãos. 
novembro, em que transformava o Instituto Sete de Setembro, antigo Abrigo de Menores, em SAM - Serviço de Assistência a Menores. Um órgão burocrático e técnico, que sistematizava, fiscalizava, regulamentava as verbas orçamentárias destinadas à Assistência Social e orientador técnico e pedagógico das instituições oficiais e particulares de atendimento ao menor ${ }^{21}$.

O SAM ficava subordinado ao MJNI e ao Juizado de Menores do Distrito Federal $^{22}$, que antes da criação deste possuía uma dupla função de atender a parte judiciária e a parte administrativa das mais de 18 instituições de atendimento ao menor vinculadas ao Juizado ${ }^{23}$.

Durante a discussão do projeto de criação do SAM foram ponderadas algumas questões pelo Ministro da Justiça que analisou o projeto. Sendo assim, com o decreto, Getúlio Vargas centralizou a assistência ao menor.

Para Vicente Faleiros, havia uma intenção em aparelhar a sociedade: "a implantação do SAM tem mais a ver com a questão da ordem social do que da assistência propriamente dita" (FALEIROS, 1995, p. 252). Percebemos uma continuada política de normatização da sociedade, sujeição e ordenamento do menor, demonstrando que a maior preocupação do governo era o controle social e não especificamente o amparo ao menor.

O SAM deveria ser o órgão sistematizador e orientador no Distrito Federal da execução das atividades de assistência aos menores sob a tutela do juiz de menores, assim como velar pela unidade e uniformidade de ação no serviço de proteção a crianças e adolescentes internados nas unidades de atendimento, contudo continuaria a cargo do Juizado a fiscalização do regime disciplinar e educativo dos internados, seguindo a legislação vigente na época.

Os objetivos do SAM, constantes no decreto-lei que o instituiu, nada mais eram do que a continuidade das ideias e das práticas correntes no atendimento ao menor até o momento. O diferencial estava na pretensão do SAM em controlar os serviços de assistência e reduzir, mediante ações educacionais,

\footnotetext{
${ }^{21}$ Adaptado. BRASIL. Decreto-lei 3.799 de 05 de novembro de 1941. Transforma o Instituto Sete De Setembro em Serviço de Assistência a Menores e dá outras Providências. Disponível em: https://www2.camara.leg.br/legin/fed/declei/1940-1949/decreto-lei-3799-5-novembro-1941413971-publicacaooriginal-1-pe.html acessado 17/10/2018

22 Idem.

${ }^{23}$ Instituições listadas no quadro $\mathrm{n}^{0} 2$ deste artigo.
} 
médicas e psicológicas, os problemas dos menores desvalidos e os em conflitos com a lei.

O SAM retirava do juizado de menores o caráter executor que este carregava até então. Portanto, não caberia mais ao juizado as funções de organizar os serviços de assistência, realizar as pesquisas e análises dos dados e prestar o tratamento aos menores. Ficava a cargo deste a fiscalização do regime disciplinar e educativo dos internatos, de acordo com a legislação vigente. ${ }^{24}$ Demonstrando, inclusive, que as funções e atribuições do diretor do SAM e do Juiz de Menores eram diferentes, não havendo nenhum tipo de conflito (NETO, 1942, p. 12).

Este órgão foi o único estabelecimento de triagem do Brasil, interligado a diversas instituições de ensino do Distrito Federal e a duas de Minas Gerais. Por ser um lugar de triagem de menores, sua função não era muito compreendida pela sociedade, o que gerou diversas críticas em relação ao não oferecimento de um ensino de qualidade. Tais críticas foram confrontadas pelo então diretor Dr. Meton de Alencar Neto no relatório dos Arquivos do Serviço de Assistência a Menores, publicado anualmente.

$\mathrm{Na}$ edição do ano 1943, o diretor explicava que por ser um estabelecimento de triagem, não tinha como este oferecer educação primária, secundária ou formação técnica aos menores que ali chegavam. O SAM recebia crianças em idade escolar, contudo o tempo que permaneciam ali era curto, não possibilitando um ensino regular. O que era possível fazer no período em que o menor estava recolhido no órgão seria o que estava disposto em suas funções. Quando a criança chegava, entregue pelo Juizado ou mesmo pelo responsável, havia a acolhida, providenciando higiene pessoal. Posteriormente eram realizados exames clínicos, feitos por médicos e biólogos, em seguida o menor passava por exames psicológicos e pedagógicos. Os técnicos do SAM de posse do diagnóstico, a partir desses exames do estado de saúde, da escolaridade, do coeficiente intelectual, do nível social e econômico, analisavam a melhor conduta técnica, ou seja, para qual instituição, vinculada ao SAM, seria enviado esse menor (NETO, 1942, p. 14).

24 Idem. Art. $6^{\circ}$ 
De acordo com Meton de Alencar Neto, o menor não permanecia nem mesmo um mês naquele estabelecimento, inviabilizando um ensino formal, regular e sistematizado. $\mathrm{O}$ que se realizava, no período em que aquele jovem estava ali, era criar o "hábito de frequência ao ambiente escolar e de convívio com livros e coisas sadias, o método da vida cotidiana e a disciplina, tanto do corpo quanto da alma" (NETO, 1942, p. 14).

O SAM era constituído de um Órgão Central, que compreendia: Secção de Administração (S. A.); Secção de Pesquisas e Tratamento Sômato-psiquico (S. P. T.); Secção de Triagem e Fiscalização (S. F. T.); Secção de Pesquisas Sociais e Educacionais (S. S. E.). A parte executória do SAM era composta pelo Instituto Profissional Quinze de Novembro, posteriormente chamada de Escola Quinze de Novembro; a Escola João Luiz Alves; o Patronato Agrícola Artur Bernardes; o Patronato Agrícola Venceslau Braz. ${ }^{25}$

Em 1944 o SAM sofreu algumas modificações em sua organização, com a reestruturação o órgão central ficou constituído da seguinte forma: Seção de Orientação e Coordenação (S.O.C.); Seção de Diagnóstico e Tratamento Médico (S.D.T.); Seção de Pesquisas Pedagógico-Sociais (S. P. S.); Seção de Colocação e Ajustamento de Menores (S.G.M.); Alojamento Provisório (A.P.) e Seção de Administração (S.A.). Ao órgão executor foi incluído a Escola Feminina de Artes e Ofício, Pavilhão Anchieta (P.A) e Hospital Central (H.C.). ${ }^{26}$

Ficou a cargo do SAM a responsabilidade de sistematizar, organizar e orientar a assistência aos menores desvalidos e delinquentes, ficando a ele subordinados os estabelecimentos oficiais (institutos e patronatos agrícolas) e, consequentemente ao MJNI. Como já abordado anteriormente, os estabelecimentos particulares, que atendiam ao juizado, firmavam um contrato com o órgão. Esses estabelecimentos podiam ser particulares sob contrato, ou seja, conveniados com o SAM, porém, administrados por particulares, os quais recebiam verbas do MJNI ou do MES - Ministério da Educação e Saúde, eram fiscalizados e recebiam apoio técnico do SAM (NETO, 1942, p. 15).

25 BRASIL. Decreto-lei 3.799 de 05 de novembro de 1941. Disponível em: https://www2.camara.leg.br/legin/fed/declei/1940-1949/decreto-lei-3799-5-novembro-1941413971-publicacaooriginal-1-pe.html acessado 17/10/2018

${ }^{26}$ BRASIL. Decreto ${ }^{0} 16.575$, de 11 de setembro de 1944. Aprova o Regimento do Serviço de Assistência a Menores do Ministério da Justiça e Negócios Interiores. Disponível em: https://www2.camara.leg.br/legin/fed/decret/1940-1949/decreto-16575-11-setembro-1944327309-publicacaooriginal-1-pe.html acessado em 11/05/2019. 
Outra categoria de estabelecimentos, eram os particulares onde os menores, abandonados ou delinquentes, eram internados através do SAM, por determinação judicial e que recebiam pagamento per capita de mensalidade. $\mathrm{Ou}$ seja, para cada criança internada nessa instituição, a partir da triagem do SAM, após recolhimento do Juizado de Menores, havia um pagamento mensal, com valor determinado pelo SAM juntamente com o MJNI (NETO, 1942, p. 15).

Havia também os estabelecimentos particulares que colaboravam com os cuidados dos menores de forma gratuita (NETO, 1942, p. 15). Instituições filantrópicas que, de acordo com as fontes, prestavam o atendimento ao menor abandonado a partir de um ideal de caridade. Infere-se, pelo nome dessas instituições, que eram estabelecimentos dirigidos por organizações cristãs.

A Casa Maternal Melo Matos, o Recolhimento Infantil Artur Bernardes, a Casa das Mãezinhas e o Abrigo Feminino recebiam subvenções do MES e a Escola Alfredo Pinto e o Patronato Getúlio Vargas recebiam subvenções do MJNI; estabelecimentos subvencionados pelo governo e administrados por organizações particulares. Recebiam, como nos outros casos, apoio técnico e fiscalização por parte do SAM (NETO, 1942, p. 15). A vinculação destas instituições com o SAM era na prática a mesma que existia desde o final da década de 20.

Quadro 1 - Classificação dos Estabelecimentos de Assistência ao Menor no Distrito Federal

\begin{tabular}{|l|l|l|c|}
\hline $\begin{array}{l}\text { Tipo } \\
\text { Estabelecimento }\end{array}$ & \multicolumn{2}{|c|}{ Nome dos Estabelecimentos } & $\begin{array}{l}\text { Público } \\
\text { Alvo(menores) }\end{array}$ \\
\hline Oficiais & $\begin{array}{l}\text { 1- Inst. Profissional Quinze de } \\
\text { Novembro (IPQN) } \\
\text { 2- Escola João Luiz Alves } \\
\text { (EJLA) }\end{array}$ & $\begin{array}{l}\text { 3- Patronato Agrícola Artur } \\
\text { Bernardes (PAAB) } \\
\text { 4- Patronato Agrícola Venceslau } \\
\text { Brás (PAVB) }\end{array}$ & sexo masculino \\
\hline Sob Contrato & $\begin{array}{l}\text { 1- Asilo Agrícola Santa Izabel } \\
\text { 2- Instituto Profissional Getúlio } \\
\text { Vargas } \\
\text { 3- Patronato Agrícola Campos } \\
\text { Sales }\end{array}$ & $\begin{array}{l}\text { 4- Patronato Agrícola Delfim } \\
\text { 5- Patronato Agrícola Lindolfo } \\
\text { Coimbra }\end{array}$ & sexo masculino \\
\hline $\begin{array}{l}\text { Colaboração } \\
\text { gratuita }\end{array}$ & $\begin{array}{l}\text { 1- Asilo Nossa Senhora de } \\
\text { 2- Orfanato Santo Antônio }\end{array}$ & $\begin{array}{l}\text { 3- Fundação Romão Matos Duarte } \\
\text { - Santa Casa de Misericórdia }\end{array}$ & $\begin{array}{c}\text { Sexo feminino e } \\
\text { misto }\end{array}$ \\
\hline
\end{tabular}




\begin{tabular}{|c|c|c|c|}
\hline $\begin{array}{l}\text { Particulares sob } \\
\text { contrato "per } \\
\text { capita" }\end{array}$ & $\begin{array}{l}\text { 1- Escola Maria Rayth } \\
\text { 2- Instituto Santo Antônio } \\
\text { 3- Instituto Jackson de } \\
\text { Figueiredo } \\
\text { 4- Serviço de Obras Sociais } \\
\text { (SOS) } \\
\text { 5- Asilo Isabel } \\
\text { 6- Instituto Mario de Andrade } \\
\text { Ramos } \\
\text { 7- Asilo Bom Pastor } \\
\text { 8- Orfanato da Pequena } \\
\text { Cruzada } \\
\text { 9- Escola Moreira } \\
\text { 10- Orfanato São José }\end{array}$ & $\begin{array}{l}\text { 11- Escolas Profissionais } \\
\text { Salesianas } \\
\text { 12- Abrigo Maria Imaculada } \\
\text { 13- Casa da Criança } \\
\text { 14- Orfanato Evangélico } \\
\text { 15- Orfanato Santa Rita de Cássia } \\
\text { 16- Educandário Sagrada Família } \\
\text { 17- Pio Brasileiro } \\
\text { 18- Instituto Muniz Barreto } \\
\text { 19- Ginásio Vasco da Gama }\end{array}$ & $\begin{array}{l}\text { Para ambos os } \\
\text { sexos, em } \\
\text { separado }\end{array}$ \\
\hline $\begin{array}{l}\text { Órgãos } \\
\text { particulares } \\
\text { subvencionados }\end{array}$ & $\begin{array}{l}\text { Associação Tutelar de Menores } \\
\text { 1- Casa Maternal Melo Matos } \\
\text { 2- Recolhimento Infantil Artur } \\
\text { Bernardes } \\
\text { 3- Casa das Mãezinhas }\end{array}$ & $\begin{array}{l}\text { Patronato de Menores } \\
\text { 1- Abrigo Feminino } \\
\text { 2- Escola Alfredo Pinto } \\
\text { 3- Patronato Getúlio Vargas }\end{array}$ & $\begin{array}{c}\text { Para ambos os } \\
\text { sexos, em } \\
\text { separado e misto }\end{array}$ \\
\hline
\end{tabular}

Conforme descrito na alínea $\mathrm{C}$ do artigo segundo do Decreto-lei da criação do SAM, o atendimento do referido órgão era exclusivo ao Distrito Federal. Exceção dos Patronatos Agrícolas de Minas Gerais ${ }^{27}$ que recebiam menores enviados primeiro pelas delegacias em convênio com o Ministério da Agricultura, Indústria e Comércio (MAIC) (OLIVEIRA, 2003), depois pelo Juizado do Distrito Federal e só a partir de 1941, pelo SAM. Inicialmente o SAM figurava como um órgão que orientava os serviços de assistência de outros estados divulgando normas de trabalho e resultados de pesquisas e estudos, oportunizando aos Estados a possibilidade de delinear suas instituições oficiais e sob contrato como as da capital federal. O SAM passou, também, a ser um órgão de formação de pessoal técnico para atuação na assistência em instituições estaduais ou municipais (PILOTTI; RIZZINI, 2009, p. 265).

A partir do Decreto-lei no 6.865 de 11/9/1944, o SAM passou a atender em todo país prestando aos menores desvalidos e transgressores da lei, auxiliando-os sob todos os aspectos. Dessa forma, o SAM ganhou amplitude de

\footnotetext{
${ }^{27}$ Adriana Viana analisa que os Patronatos Agrícolas foram criados com a finalidade de reformar o menor através do trabalho, valorizando a lógica ordem/trabalho, baseados no controle social. O envio de menores para os Patronatos possuía, também, a ideia de controle do espaço urbano e rural, assim como tinha como meta pedagógica o ordenamento através da rigidez do controle sobre os menores para lá encaminhados e o ensinamento do trabalho no campo. Para esses estabelecimentos eram enviados os menores abandonados, vadios ou delinquentes, que para o poder policial e judicial, precisavam reformar o modo de vida e pensar, igualmente afastar-se do meio urbano. Adriana Viana faz uma análise sobre os Patronatos analisando posturas governamentais sobre colonização e controle do espaço rural, contudo essa não é a nossa intenção nesse trabalho. (VIANNA, 1999a, p. 76)
} 
ação em todo território nacional, assim como competia ao órgão abrigar menores autorizados pelo juizado de menores, diferenciando do decreto que criou o SAM que competia abrigar os menores à disposição no referido juizado. Já que até 1944 esse órgão recebia menores encaminhados pelo Juiz de Menores, realizava uma triagem e encaminhava para a instituição que melhor atendesse a necessidade daquele indivíduo. Contudo a operacionalização do Serviço nas demais unidades federativas não foi explicada no referido decreto ou, mesmo, no regimento do órgão.

O quinto artigo do decreto de criação do SAM tratava da responsabilidade do órgão quanto às subvenções pagas pelo governo aos estabelecimentos oficiais e particulares que atendiam aos menores, determinando que somente após a observação e checagem criteriosa dos técnicos do SAM essas verbas seriam concedidas. ${ }^{28}$

Os técnicos do Departamento Administrativo do Serviço Público (DASP) analisaram, na época, que o exame do pedido de subvenção pelo SAM poderia, sem maiores problemas, ocorrer anteriormente a análise do Conselho Nacional de Serviço Social - CNSS, visto que através do Serviço de Assistência a Menores haveria uma melhor seleção, amparando somente as instituições providas de organização administrativa e documental adequadas, proporcionando benefícios aos cofres públicos (NETO, 1942, p. 13).

Os jornais, em 1941, abordaram a criação do SAM, dando um enfoque ao fato do referido órgão passar a controlar a distribuição das subvenções entre as instituições que abrigavam os menores desvalidos ou delinquentes, demonstrando que o assunto gerava preocupações na opinião pública. ${ }^{29}$

28 BRASIL. Decreto-lei 3.799 de 05 de novembro de 1941. Disponível em: https://www2.camara.leg.br/legin/fed/declei/1940-1949/decreto-lei-3799-5-novembro-1941413971-publicacaooriginal-1-pe.html acessado 17/10/2018

29 Sobre isso ver: Jornal Diário de Notícias, de 20 de agosto de 1941. Ed. 5.772, pág. 4. Fonte: Biblioteca Nacional. Hemeroteca Digital. Disponível em: http://memoria.bn.br/DocReader/DocReader.aspx?bib=093718_02\&PagFis=11595\&Pesq=Ser vi\%c3\%a7o\%20de\%20Assist\%c3\%aancia\%20a\%20menores

Jornal do Brasil, de 22 de agosto de 1941. Ed. 197, pág. 10. Fonte: Biblioteca Nacional. Hemeroteca Digital Disponível em: http://memoria.bn.br/DocReader/DocReader.aspx?bib=030015_o6\&pesq=Serviço\%20de\%20 Assistência\%20a\%20menores\&pasta=ano\%20194

Correio da Manhã, o8 de novembro de 1941. Ed. 14.423, pág. 3. Fonte: Biblioteca Nacional. Hemeroteca Digital. Disponível em: http://memoria.bn.br/DocReader/DocReader.aspx?bib=089842_05\&pesq=Serviço\%20de\%20 Assistência\%20a\%20menores\&pasta=ano\%20194 
Os periódicos também traziam informações sobre o pagamento a estabelecimentos particulares via pagamento na modalidade per capita. Havia, por parte da opinião pública dúvidas em relação a esses estabelecimentos e as mensalidades recebidas por eles. O estabelecimento particular que recebia crianças do SAM, via juizado de menores, não precisava realizar um contrato com o referido serviço. ${ }^{30}$

Como relatava o então diretor do SAM, Raul de Matos e Silva, na Câmara dos Deputados ${ }^{31}$, havia dois tipos de estabelecimentos particulares que recebiam recursos do SAM, sendo eles os que firmavam contrato com o órgão e consequentemente eram pagos com recursos do próprio SAM e os estabelecimentos que recebiam referente a cada menor lá internado a pedido do referido órgão, como já citado, recebendo per capita.

Procuramos em leis, decretos, decretos-lei publicados desde o início do século XX e não encontramos informações sobre a obrigatoriedade de realização de contrato entre os estabelecimentos particulares, que recebiam por cada criança internada neles, e o Estado. O relatório do MJNI, compreendendo os anos de 1946 a 1948, descreve que os

estabelecimentos particulares subordinados e articulados com o
S.A.M. deixaram de cooperar com o Serviço, em vista de considerarem
o pagamento mensal de Cr\$ 160,oo [per capita] insuficiente, e tendo
em vista que a Prefeitura do Distrito Federal e a Legião Brasileira de
Assistência pagam Cr\$ 360 ,oo exatamente nas mesmas condições. ${ }^{32}$
(Grifo nosso)

Em razão da ausência de uma norma legal, observando o relatório do MJNI e a partir da fala do diretor do Serviço de Atendimento ao Menor de que realmente não havia um contrato entre o SAM e o estabelecimento particular,

A Noite, de 19 de agosto de 1941. Ed. 10.604, pág. 1 e 3. Fonte: Biblioteca Nacional. Hemeroteca Digital. Disponível

em: http://memoria.bn.br/DocReader/DocReader.aspx?bib=348970_o4\&pesq=Serviço\%20de\%20 Assistência\%20a\%20menores\&pasta=ano\%20194 Acesso 23/03/2019

3o Idem.

$3^{1}$ Depoimento de Raul de Matos e Silva, diretor do SAM, ao relator da CPI, deputado Rubens Berardo, no dia 24 de abril de 1956. Pág. 53. Arquivo da Câmara dos Deputados. Origem dos Documentos: Coordenação de Comissões Temporárias. Fundo Arquivístico: CPI para apurar irregularidades ocorridas no Serviço de Assistência a Menores (SAM).

${ }^{32}$ Ministério da Justiça e Negócios Interiores. Relatório das Atividades do Exercício de 1946. Apresentado a sua Excelência o Senhor Presidente da República, General de Divisão Eurico Gaspar Dutra, pelo Senhor Ministro de Estado, Douctor Benedicto Costa Netto. Serviço de Documentação. Rio de Janeiro $1947 . \quad$ Disponível em: http://memoria.bn.br/DocReader/DocReader.aspx?bib=ZBo031\&PagFis=399 Acessado em: 10/05/2019. 
configurando-o como um prestador de serviço para o SAM, observamos uma ausência de critérios administrativos, assim como uma ausência de autonomia na condução do SAM. Diante disso é importante analisar a administração interna do SAM e os problemas percebidos nas fontes.

\section{1- Administração Interna do SAM e seus problemas}

A administração do SAM apresentava diversos problemas. Um deles era em relação à contratação do pessoal. Os funcionários não concursados do órgão eram contratados via MJNI sem a anuência do diretor do SAM, embora no regimento do órgão constasse que uma das funções do diretor era "admitir e dispensar, na forma da legislação, o pessoal extranumerário”. 33

Segundo o decreto de criação, o SAM seria composto por pessoal permanente, que era constituído de: cargos isolados, de provimento em comissão; cargos isolados e de carreira, de provimento efetivo via concurso e funções gratificadas. Outra categoria existente no SAM era os de extranumerários mensalistas, todos esses cargos eram contratados pelo MJNI.

A seleção de pessoal permanente era feita pela Divisão de Seleção e Aperfeiçoamento do DASP, que era o órgão que cuidava da seleção de todo o pessoal do Serviço Público. Já os funcionários extranumerários eram contratados, segundo os ex-diretores do SAM, Meton de Alencar Neto e Padre Negromonte, diretamente pelo Ministro da Justiça. ${ }^{34}$

Além dos órgãos executores no Distrito Federal e em Minas Gerais, em $1953^{35}$ foram criadas 8 (oito) inspetorias, considerando que ao Serviço de Assistência a Menores (SAM), de acordo com sua legislação orgânica, competia prestar assistência, em todo o território nacional, a menores desvalidos e em conflito com a lei e que, evidenciava-se a necessidade de tornar-se efetiva, em

33 BRASIL. Decreto ${ }^{0}$ 16.575, de 11 de setembro de 1944. Aprova o Regimento do Serviço de Assistência a Menores do Ministério da Justiça e Negócios Interiores. Disponível em: https://www2.camara.leg.br/legin/fed/decret/1940-1949/decreto-16575-11-setembro-1944327309-publicacaooriginal-1-pe.html Acessado em 11/05/2019.

34 Depoimento de Meton de Alencar Netto, ex-diretor do SAM, ao relator da CPI, deputado Rubens Berardo no dia 19 de abril de 1956. Pág. 2-4. Arquivo da Câmara dos Deputados. Origem dos Documentos: Coordenação de Comissões Temporárias. Fundo Arquivístico: CPI para apurar irregularidades ocorridas no Serviço de Assistência a Menores (SAM).

35 O regimento interno do SAM, datado de 1944, ampliava o atendimento do órgão para todo o território nacional, contudo isso só foi efetivado a partir de 1946. Sendo que em 1953 é que o Ministro da Justiça criou a Portaria 125, em 10 de junho, que dispunha sobre as atividades do Serviço de Assistência a Menores nos estados. 
todo o território, visto a sua extensão, a ação executiva, orientadora e fiscalizadora do serviço, o qual somente se pudesse alcançar pela instalação de unidades sediadas no interior do país. ${ }^{36}$ Foram criadas oito regiões e cada inspetoria foi instalada na sede dessas regiões, ficando distribuídas dessa forma:

Quadro 2 - Inspetorias do Serviço de Assistência a Menores - Regiões e Estados

\begin{tabular}{|l|l|l|}
\hline \multicolumn{1}{|c|}{ Regiões } & \multicolumn{1}{|c|}{ Sede } & \multicolumn{1}{c|}{ Estados compreendidos } \\
\hline $1^{\text {a }}$ Região & Belém & $\begin{array}{l}\text { Amazonas, Pará, Território Federais do Acre, Amapá, Rio Branco e } \\
\text { Guaporé }\end{array}$ \\
\hline $2^{\text {a }}$ Região & Fortaleza & Maranhão, Piaú́, Ceará \\
\hline $3^{\text {a }}$ Região & Recife & Rio Grande do Norte, Paraíba e Pernambuco \\
\hline $4^{\text {a }}$ Região & Salvador & Alagoas, Sergipe e Bahia \\
\hline $5^{\text {a } \text { Região }}$ & Niterói & Espírito Santo e Estado do Rio de Janeiro \\
\hline $6^{\text {a } \text { Região }}$ & São Paulo & Mato Grosso e São Paulo \\
\hline $7^{\text {a }}$ Região & Belo Horizonte & Minas Gerais e Goiás \\
\hline $8^{\text {a Região }}$ & Porto Alegre & Paraná, Santa Catarina e Rio Grande do Sul \\
\hline
\end{tabular}

Nos estados referentes a cada região, excetuando o estado sede, foram criadas agências integradas as inspetorias e nas cidades do interior que tivessem um mínimo de quarenta mil habitantes, a existência de uma jurisdição de no mínimo mil menores desvalidos e pelo menos cem menores internados em instituições situadas na área de jurisdição, foram criadas subagências que integravam-se às agências que se integravam às inspetorias. 37

As inspetorias possuíam a competência, dentro da respectiva área de jurisdição, de verificar os estabelecimentos pelo qual se recomendaria a internação de menores pelo SAM; informar às instituições sobre normas e regras que se dispunham para receber menores; internar os desvalidos em estabelecimentos particulares; manter como no órgão central prontuários com dados e documentos relativos às crianças e adolescentes atendidos. Assim como comunicar imediatamente ao SAM todas as internações que promovesse diretamente ou por intermédio das Subagências instaladas no Estado, informando em relação a cada menor: nome, filiação, data e local do nascimento, antecedentes sociais, data da internação, índice de escolaridade, condições de saúde, norte e localização do estabelecimento. ${ }^{38}$

${ }_{36}^{6}$ Ministério da Justiça e Negócios Interiores. Gabinete do Ministro. Portaria 125 de 10 de junho de 1953. Diário Oficial da União, Seção I, pág. 10.474, 12 de junho de 1953.

37 Ministério da Justiça e Negócios Interiores. Gabinete do Ministro. Portaria 125 de 10 de junho de 1953. Diário Oficial da União, Seção I, pág. 10.474, 12 de junho de 1953.

38 Idem. 
A Portaria estabelecia, inclusive, que as Inspetorias, Agências e Subagências, seriam dirigidas, respectivamente, por Inspetores Regionais, Agentes e Subagentes, designados pelo Ministro de Estado, sendo somente os subagentes recomendados mediante proposta do diretor do SAM. 39

Com a criação das inspetorias e das agências houve um aumento no número de funcionários ligados ao SAM. É importante salientar dois aspectos, primeiro o caráter seletivo das contratações de inspetores e agentes, visto ser de competência do ministro da justiça à contratação de tais funcionários, segundo que inspetores regionais e agentes eram, portanto, funcionários extranumerários que inchavam o SAM e não possuíam qualificação técnica para tal função.

Paulo Nogueira Filho, em seu livro Sangue, corrupção e vergonha, relatava que em decorrência do aumento dessas inspetorias a antessala do gabinete do diretor do SAM passou a ficar cheia de pessoas pedindo emprego para si ou para seus familiares. Dentre esses pedintes

Generais se faziam acompanhar de Generais Assistentes; deputados, de senadores; senadores e deputados por governadores e governadores por suas bancadas, tudo para a obtenção de empregos para sinecuristas. O que toda essa multidão pleiteava era mais um gancho no cabide de empregos para seus filhos, filhas, sobrinhos, parentes ou amigos. (FILHO, 1956, p. 255)

Durante os depoimentos na CPI do SAM, o Deputado Federal Aarão Steinbruch relatava que havia assistido a dois programas de televisão e neles houve uma participação do Ex-diretor do SAM, Padre Negromonte, que ao ser entrevistado reconheceu que a forma de contratação do pessoal do Serviço de Assistência a Menores era por meio de "filhotismo político".40

Demonstrando que havia um "estamento burocrático41" em que um grupo "comanda o ramo civil e militar da administração e, dessa base, com

\footnotetext{
39 Idem

40 Fala do Deputado Federal Aarão Steinbruch durante a CPI do SAM. Dia 18 de abril de 1956. Pág. 16. Arquivo da Câmara dos Deputados. Origem dos Documentos: Coordenação de Comissões Temporárias. Fundo Arquivístico: CPI para apurar irregularidades ocorridas no Serviço de Assistência a Menores (SAM).

${ }^{41}$ Raymundo Faoro, inspirado na teoria de Max Weber, interpreta a sociedade brasileira através dos conceitos de estamento e patrimonialismo. Analisa a manutenção de privilégios sociais, políticos e econômicos criando o conceito "estamento burocrático". Sobre isso ver: FAORO,
} 
aparelhamento próprio, invade e dirige a esfera econômica, política e financeira"(FAORO; COHN, 2012, p. 12). Segundo Faoro, as classes dirigentes utilizam o setor público em benefício próprio, aceitando a ideia de contratação de familiares, amigos ou pessoas para a formação de uma clientela política. Quem está no poder "fecha-se na sua perpetuidade hereditária, ao eleger os filhos e genros, com o mínimo de concessões ao sangue novo" (FAORO; COHN, 2012, p. 92).

Quadro 3 - Demonstrativo do Quadro de Pessoal - Quantidade de funcionários e característica funcional

\begin{tabular}{|c|c|c|c|c|}
\hline Ano & \multicolumn{2}{|c|}{1947} & \multicolumn{2}{|c|}{1948} \\
\hline Quadro de pessoal & permanente & extranumerário & permanente & extranumerário \\
\hline Órgão Central & 120 & 299 & 133 & 265 \\
\hline $\begin{array}{l}\text { Instituto Prof. Quinze de } \\
\text { Novembro }\end{array}$ & 256 & 52 & 245 & 49 \\
\hline $\begin{array}{l}\text { Escola Agrícola Artur } \\
\text { Bernardes }^{42}\end{array}$ & 59 & 76 & 59 & 76 \\
\hline Escola Venceslau Brás43 & 31 & 64 & 32 & 64 \\
\hline Total & 466 & 491 & 469 & 454 \\
\hline
\end{tabular}

Fonte: Relatório anual do MJNI, 1946.44

Quadro 4 -

anualmente a

SAM em 1946

\begin{tabular}{|l|c|c|}
\hline \multirow{2}{*}{} & \multicolumn{2}{|c|}{ ANO/ VALORES (Cr\$) } \\
\cline { 2 - 3 } & $\mathbf{1 9 4 6}$ & $\mathbf{1 9 4 8}$ \\
\hline Permanente & $1.929 .000,00$ & $\mathbf{2 . 1 4 6 . 8 0 0 , 0 0}$ \\
\hline
\end{tabular}

Valores pagos

funcionários do

e 1948

Raymundo; COHN, Gabriel. Os donos do poder: formação do patronato político brasileiro, 5. ed. São Paulo: Ed. Globo, 2012.

42 Antigo Patronato Agrícola Arthur Bernardes.

43 Antigo Patronato Agrícola Venceslau Brás.

44 Dados relativos ao Órgão Central. No relatório não há referência aos outros órgãos oficiais, que fazem parte do quadro executor do SAM. Ministério da Justiça e Negócios Interiores. Relatório das Atividades do Exercício de 1946. Apresentado a sua Excelência o Senhor Presidente da República, General de Divisão Eurico Gaspar Dutra, pelo Senhor Ministro de Estado, Douctor Benedicto Costa Netto. Serviço de Documentação. Rio de Janeiro 1947. Disponível em: http://memoria.bn.br/DocReader/DocReader.aspx?bib=ZBoo31\&PagFis=399 Acessado em: 10/05/2019. 


\begin{tabular}{|l|r|r|}
\hline Extranumerário & $5.138 .400,00$ & $4.768 .200,00$ \\
\hline $\begin{array}{l}\text { Função } \\
\text { Gratificada }\end{array}$ & $73.800,00$ & $68.400,00$ \\
\hline
\end{tabular}

Fonte: Relatório do SAM de 1946 e Relatório do MJNI de 1948.45

No órgão central, como podemos observar na Quadro 4, havia mais que o dobro de funcionários extranumerários mensalistas, questão recorrente na assistência ao menor. Segundo Rizzini, no final da década de 1920:

\begin{abstract}
A Escola João Luís Alves, criada em 1926 para "regenerar pelo trabalho, educação e instrução" os menores delinquentes recolhidos pelo Juízo (Decreto n. 15.508 de 4/11/26), apresentava abundantes exemplos dos problemas apontados acima: cada aluno custava por mês $720 \$ 000$, enquanto nos estabelecimentos administrados por associações civis esse custo não passava de 150\$000 mensais; havia 52 funcionários para 70 alunos (em visita à Escola, por ocasião da fuga de 13 menores, Sabóia Lima constatou que havia apenas 58 alunos para 60 funcionários); vaga de professor ocupada por um sargento da polícia etc.(PILOTTI; RIZZINI, 2009, p. 254) [Grifo nosso]
\end{abstract}

Observando o Quadro 5 podemos analisar que os gastos com os extranumerários eram muito superiores ao que se gastava com os funcionários efetivos. O valor pago aos extranumerários era 266\% maior que aos empregados concursados, considerando o número superior de funcionários nessa categoria. Em 1939, o juiz de menores Augusto Sabóia Lima, escreveu um relatório sobre o juizado de menores e verificou que "o dispêndio com cada aluno na Escola é superior ao que gasta uma família rica para manter um filho no mais caro dos colégios do Rio de Janeiro”. (LIMA Apud PILOTTI; RIZZINI, 2009) Percebemos que velhas práticas não se extinguiram com o surgimento do SAM.

Percebemos, também, que o dinheiro pago a servidores extranumerários era mal aplicado, na maioria das vezes, visto não serem eles profissionais capacitados para o trabalho com crianças e adolescentes em risco social. O jornalista Daniel Caetano, escreveu, no jornal Diário de Notícias, edição 7.287, de 27 de julho de 1946, sobre o Serviço de Assistência a Menores, após passar quatro horas no Instituto Quinze de Novembro, dos muitos problemas

45 Ibid. e NETO, Meton de Alencar. Arquivos do Serviço de Assistência a Menores, p. 200. 
observados por ele, a formação dos inspetores foi um ponto que lhe chamou atenção. $\mathrm{O}$ repórter questionou o secretário do diretor daquele órgão se os inspetores eram ou não homens preparados para tratar com crianças, recebendo uma resposta negativa. ${ }^{46} \mathrm{O}$ Secretário ainda afirmou que a escola não dispunha de "um corpo de inspetores a altura da missão que lhes cabe". 47

No decreto-lei, de 1941, e no regimento do SAM, de 1944, não havia nenhum dispositivo que tratasse de qualificação técnica de funcionários, muito menos exigência de tal qualificação para ingresso no quadro de funcionários do SAM. Contudo, alguns cargos, por si só, exigiam qualificação técnica, visto ser necessária a formação em escolas de nível médio ou superior para exercer tais profissões, como os da área da saúde (médicos, dentistas, enfermeiros, farmacêuticos, biólogos, entre outros), os da área da educação (pedagogos, professores, bibliotecário) e os assistentes sociais.

Essa ausência de exigência de qualificação técnica, segundo a análise das fontes, era um fator que trazia problemas ao funcionamento do SAM. Visto que, em sua maioria os trabalhadores extranumerários proporcionavam às crianças e adolescentes momentos desagradáveis, envolvendo violência, humilhação e maus tratos (FILHO, 1956).

No relatório do Serviço de Assistência a Menores do ano de 1946, o diretor Meton de Alencar Neto escrevia que dentre os muitos problemas que aquele órgão vinha enfrentando, parte deles se dava pela

impropriedade das instalações e a deficiência de pessoal habilitado proporciona incidentes diários, exercendo sobre $o$ menor, que nele tem o primeiro contato com o serviço, uma impressão desagradável que influi consideravelmente sobre toda a atitude em face do SAM. ${ }^{8}$ [Grifo Nosso]

Relatava, ainda, que:

\footnotetext{
${ }^{46}$ Diário de Notícias. Edição 7.287 de 27 de julho de 1946, página 3. Fonte: Biblioteca Nacional. Hemeroteca Digital. Disponível em: http://memoria.bn.br/DocReader/DocReader.aspx?bib=093718_02\&PagFis=38491\&Pesq=ser vi\%c3\%a7o\%20de\%20assist\%c3\%aancia\%20a\%20menores Acessado em: 17/o5/2019 47 Idem.

${ }^{48}$ No relatório não há referência aos outros órgãos oficiais, que fazem parte do quadro executor do SAM. Ministério da Justiça e Negócios Interiores. Relatório das Atividades do Exercício de 1946. Apresentado a sua Excelência o Senhor Presidente da República, General de Divisão Eurico Gaspar Dutra, pelo Senhor Ministro de Estado, Douctor Benedicto Costa Netto. Serviço de Documentação. Rio de Janeiro 1947. Disponível em: http://memoria.bn.br/DocReader/DocReader.aspx?bib=ZBoo31\&PagFis=399 Acessado em: 10/05/2019.
} 
Na verdade, é que há batalhadores e incansáveis servidores do SAM, ainda do meu tempo, que se dedicam de maneira idealista e verdadeiramente louvável à recuperação dos menores. Mas a recuperação não depende apenas dessa devoção; depende de técnica, depende de planejamento, depende de seleção e, sobretudo, de triagem. Não se compreende um organismo como o SAM sem uma aparelhagem perfeita de triagem, na qual se selecionar grupos homogêneos, procurando-se do mesmo passo especificar o trabalho de cada uma das instituições. 49

O ex-diretor confirmou o problema de falta de qualificação dos funcionários do SAM e explicou ao Deputado Federal Rubens Berardo, durante depoimento na CPI do SAM, que ele havia criado, em 1946, duzentos e cinquenta cargos de inspetor de alunos. No entanto, com o fim da Segunda Guerra Mundial, o Governo Federal alocou os homens que haviam se dedicado ao serviço de defesa passiva nessas vagas criadas no SAM.50 Meton afirmava que todo o trabalho de planejamento, estudo e seleção de pessoal criado por ele, teve que ser posto de lado. Consequentemente a carreira de inspetor de alunos começou a funcionar mal. $5^{1}$

Outro ponto nevrálgico no SAM era a falta de autonomia em pontos importantes para o bom funcionamento do serviço. Segundo o decreto de criação e o regimento do órgão o SAM possuiria autonomia de decisão e ação em relação ao menor, contudo não possuía autonomia dos meios e recursos para que as decisões e ações pudessem ser prontamente atendidas. ${ }^{2}$

O SAM era um órgão subordinado ao MJNI e, portanto, dependia de outros órgãos do próprio Ministério para a condução de suas atividades. A vinculação que existia entre o serviço e o Departamento de Administração era a mesma de todos os outros órgãos existentes no MJNI. O Departamento de Administração era divido em: Direção Geral, Divisão de Pessoal, Divisão de

\footnotetext{
49 Depoimento de Meton de Alencar Netto, ex-diretor do SAM, ao relator da CPI, deputado Rubens Berardo no dia 19 de abril de 1956. Pág. 9. Arquivo da Câmara dos Deputados. Origem dos Documentos: Coordenação de Comissões Temporárias. Fundo Arquivístico: CPI para apurar irregularidades ocorridas no Serviço de Assistência a Menores (SAM).

5o Idem.

${ }^{51}$ Idem.

${ }^{2}$ BRASIL. Decreto ${ }^{0}$ 16.575, de 11 de setembro de 1944. Aprova o Regimento do Serviço de Assistência a Menores do Ministério da Justiça e Negócios Interiores. Disponível em: https://www2.camara.leg.br/legin/fed/decret/1940-1949/decreto-16575-11-setembro-1944327309-publicacaooriginal-1-pe.html acessado em 11/05/2019.
} 
Orçamento, Divisão de Material e Divisão de Obras, que eram destinadas a oferecer os meios para que as repartições afins pudessem trabalhar.

É preciso elucidar que teoricamente o Departamento de Administração do MJNI não interferia nas decisões e nas atividades do SAM. Contudo, analisando o extenso documento produzido pela CPI do SAM, diretores e exdiretores do referido órgão afirmaram que em alguns casos eles não possuíam autonomia de decisão. Em parte, em decorrência da organização burocrática criada pelo MJNI e em parte por quebra do sistema vigente, burla das normas. 53

Elucidamos, também, que todas as repartições do Ministério tinham programas específicos elaborados com determinada antecedência, que o objeto da proposta orçamentária precisava ser feito com prazo certo e determinado. A proposta orçamentária de cada repartição era discutida pelo DASP, posteriormente era encaminhada ao Congresso Nacional para ser votada, dentro do prazo de votação do orçamento. De acordo com a dotação orçamentária existente no orçamento de cada repartição e de acordo com o pedido dos diretores o Departamento de Administração trabalhava para atender as necessidades apresentadas. 54

O Departamento de Administração do ministério, como supracitado, não deveria interferir nas propostas das repartições, ficando a cargo, somente, de verificar se a proposta estava correta, se apresentava alguma falha que poderia levar a uma reprovação por parte do Congresso. Essa análise era realizada por cada divisão dentro do Departamento de Administração, ou seja, proposta de material era analisada pela Divisão de Material, passava pela Divisão de Orçamento e depois pela Administração. Aprovada a proposta, retornava para a Divisão de Material, que fazia a licitação dos produtos, realizava as compras e a distribuição.

Destarte, o SAM elaborava a proposta orçamentária, com o apoio dos técnicos dos departamentos internos do órgão. Esse plano deveria conter todas

53 Depoimento de Bento Queiroz de Barros Junior, Diretor do Departamento de Administração do MJNI, ao relator da CPI, deputado Rubens Berardo no dia 24 de abril de 1956. Pág. 53. Arquivo da Câmara dos Deputados. Origem dos Documentos: Coordenação de Comissões Temporárias. Fundo Arquivístico: CPI para apurar irregularidades ocorridas no Serviço de Assistência a Menores (SAM). CPI do SAM.

54 Depoimento de Raul de Matos e Silva, Diretor do SAM, ao relator da CPI, deputado Rubens Berardo no dia 18 de abril de 1956. Pág. 45. Arquivo da Câmara dos Deputados. Origem dos Documentos: Coordenação de Comissões Temporárias. Fundo Arquivístico: CPI para apurar irregularidades ocorridas no Serviço de Assistência a Menores (SAM). 
as necessidades do SAM para o ano, portanto, era calculado a quantidade de material, despesas com pessoal e a necessidade ou não de novas contratações, assim como as obras e reformas para os prédios do órgão central e dos outros estabelecimentos oficiais do SAM. 55

No entanto, nem sempre a proposta era aceita integralmente, podendo ocorrer alterações devido ao planejamento orçamentário do executivo. Nesse caso, a alteração era proposta pelo Departamento de Administração, visto ser ele que acompanhava a execução orçamentária, sabendo quando uma proposta era suficiente ou insuficiente. O SAM não interferia nisso. ${ }^{56}$

Por exemplo, alimentação e vestuário eram rubricas específicas no orçamento do MJNI, ou seja, dentro do orçamento do Ministério havia uma verba somente para compra de material, e havia demandas materiais em todos os estabelecimentos penais, instituições de acolhimento de menores e repartições do MJNI. Isto posto, o Departamento de Administração, por intermédio da Divisão de Material, tinha o controle da despesa que corria por conta dessa dotação, sabendo se seria ou não suficiente para todo o exercício.

Salientando que a proposta orçamentária era elaborada pelas repartições no mês de novembro, discutida no ano seguinte e votada no segundo ano pós elaboração da proposta, ou seja, a proposta elaborada em 1954, só seria votada em 195657. O Deputado Federal Raimundo Padilha, presidente da CPI do SAM, constatava a problemática gerada com as regras do orçamento e desabafou, na sessão de 25 de abril de 1956, que esse era "um dos vícios da elaboração orçamentária brasileira". .58

Observamos por esse exemplo que há uma incoerência burocrática nesse processo, porquanto ser difícil prever a quantidade de material (alimentos, principalmente) a serem consumidos dois anos à frente. A destinação de verbas para as repartições do MJNI era falha e gerava grande problema para os

55 Idem.

${ }^{56}$ Idem.

57 Depoimento de Bento Queiroz de Barros Junior, Diretor do Departamento de Administração do MJNI, ao relator da CPI, deputado Rubens Berardo no dia 24 de abril de 1956. Pág. 53. Arquivo da Câmara dos Deputados. Origem dos Documentos: Coordenação de Comissões Temporárias. Fundo Arquivístico: CPI para apurar irregularidades ocorridas no Serviço de Assistência a Menores (SAM).

${ }^{58}$ Fala de Raimundo Padilha, Deputado Federal, no dia 18 de abril de 1956. Pág. 15. Arquivo da Câmara dos Deputados. Origem dos Documentos: Coordenação de Comissões Temporárias. Fundo Arquivístico: CPI para apurar irregularidades ocorridas no Serviço de Assistência a Menores (SAM). 
diretores das repartições. ${ }^{59}$ No caso da alimentação, imaginemos que a tomada de preço em 1954 tenha sido $\mathrm{X}$, e que o departamento tenha realizado o planejamento levando em conta a majoração desse item, considerando o tempo de trâmite do processo de discussão e votação do orçamento, contudo, a elevação do custo de vida pode transformar essa majoração insuficiente. Tal situação geraria a necessidade de um crédito suplementar. ${ }^{60}$

Raul de Matos e Silva, durante a CPI do SAM em 1956, relatava que quem requisitava esse crédito suplementar ou verbas extra orçamentárias era o órgão em que constava a verba orçamentária, por exemplo, nos casos de itens alimentícios e vestuários seria a Divisão de Material, visto ser essa divisão detentora de conhecimento de como estavam sendo aplicadas as verbas, como estavam os desenvolvimentos dos gastos e o crescimento dos preços.

Diante disso, percebemos que o SAM não controlava as questões orçamentárias, muito menos de aquisição de produtos, o que gerava grandes dificuldades para a plena administração do órgão. As verbas do SAM estavam centralizadas nas divisões do Departamento de Administração. O ex. diretor do serviço, Meton de Alencar Neto, queixou-se sobre isso, na sessão de depoimentos da CPI do SAM:

\begin{abstract}
É preciso dizer que o SAM, tendo no seu diretor e no juiz de menores uma autoridade paternal, não pode, de modo algum, ficar jungido a peias administrativas que lhe impeçam uma ação imediata, rápida, em favor do menor. Às vezes surgem dificuldades administrativas que dificilmente o diretor pode superar. [...] Para dar um exemplo frisante das dificuldades que tem o diretor do SAM para prever as despesas de um órgão dessa natureza, vamos supor que ele tenha previsto fazer, durante um ano, 50 operações de apendicite, tenha calculado o preço total e feito constar do orçamento uma verba capaz de atender a essa despesa. Mas pode ocorrer que durante o ano faça apenas, 10 operações de apendicite ou, então, 200, e já se vê que seria necessária talvez uma pitonisa para prever despesas dessa natureza. ${ }^{61}$
\end{abstract}

59 Depoimento de Raul de Matos e Silva, Diretor do SAM, ao relator da CPI, deputado Rubens Berardo no dia 18 de abril de 1956. Pág. 45. Arquivo da Câmara dos Deputados. Origem dos Documentos: Coordenação de Comissões Temporárias. Fundo Arquivístico: CPI para apurar irregularidades ocorridas no Serviço de Assistência a Menores (SAM).

60 Idem.

61 Depoimento de Meton de Alencar Netto, ex-diretor do SAM, ao relator da CPI, deputado Rubens Berardo no dia 19 de abril de 1956. Pág. 2-4. Arquivo da Câmara dos Deputados. Origem dos Documentos: Coordenação de Comissões Temporárias. Fundo Arquivístico: CPI para apurar irregularidades ocorridas no Serviço de Assistência a Menores (SAM). 
O modelo estrutural em que foi construído o Serviço de Assistência a Menores favorecia práticas desviantes por parte dos diversos agentes públicos envolvidos no processo de cuidados com os menores. A ausência de autonomia administrativa por parte do diretor, instituída na lei e no regimento interno do órgão, contribuiu para o mau uso do bem público, proporcionando incidentes como desvio de verbas públicas, apadrinhamento político e corrupção.

\section{4- Considerações Finais}

Destarte, o artigo apresentou e analisou órgãos que foram criados dentro do executivo, a fim de facilitar a normatização, a formulação de políticas e o processo decisório nos diversos setores do governo em relação a assistência social de crianças e adolescentes. O SAM foi criado durante essa reestruturação do Estado e constituído dentro dessa lógica burocrata.

Como tudo está inserido em um tempo e em um contexto, o SAM nasce como reflexo de uma sociedade em crescimento, com uma expansão de um capitalismo (tardio, segundo os pesquisadores do período) e com um alto índice de desigualdade social. A ideia de proteção à criança sempre esteve presente na sociedade brasileira, mas, com diversas nuances. No período estudado havia um pensamento higienista e de controle social, devido a isso o Estado foi conclamado a intervir.

O SAM foi uma resposta do governo aos anseios da sociedade de "proteger" o menor, retirando-o das ruas da cidade e de garantir o desenvolvimento da nação incentivando o ensino técnico, o que resultaria em mão de obra. A organização administrativa do SAM apresentava muitos problemas, era um órgão dependente do MJNI, gerando uma falta de autonomia gerencial em diversos pontos relacionados ao atendimento ao menor.

A desorganização do Serviço, que muito se dava pelo comportamento desviante de alguns de seus funcionários e pela centralização do MJNI, provocava problemas em relação à contratação de pessoal, em que se percebe as indicações políticas, por exemplo. O número de funcionários era grande, contudo, ineficiente, pois não havia qualidade técnica de muitos dos 
trabalhadores empregados naquele Serviço. Esse acúmulo de funcionários gerava um alto gasto com folha de pagamento.

Havia, também, os problemas administrativos que produziam transações ilegítimas ou conluio em atividades ilícitas. Ações que desrespeitavam o bem público, perpassando por agentes privados e públicos.

Isto posto, infere-se que vicissitudes, encontrada nas fontes, mas não analisadas nesse artigo, como violências física, sexual e psicológica com os menores internados nas unidades oficiais e nas outras, particulares e subordinadas ao serviço decorriam em grande parte de uma estrutura administrativa mal arquitetada.

A análise sobre o atendimento às crianças e aos adolescentes no período da experiência democrática é de suma importância para a compreensão das transformações pelas quais passava a sociedade brasileira e que o controle social sobre indivíduos em vulnerabilidade e risco social ou em conflito com a lei foram peças constituintes da sociedade atual. Percebe-se a relevância historiográfica, pelo diálogo estabelecido e o aprofundamento na estrutura administrativa do SAM, assim como nos problemas iniciais no atendimento a menores.

Conforme Michel de Certeau, "enquanto a pesquisa é interminável, o texto deve ter um fim"(CERTEAU ET. ALL, 2011, p. 90). Esse texto é concluído formalmente, mas o tema não, visto não ser possível um único artigo esgotar as perspectivas de análise sobre a institucionalização do atendimento ao menor. É um tema importante e que apresenta diversas linhas de discussões, cujo aprofundamento conduz o leitor a outros questionamentos ampliando o campo de investigação. Logo, muitas lacunas permanecem e há muito o que se pesquisar e "o espetáculo da busca, com seus sucessos e reveses, raramente entedia”(LE GOFF, 2013).

\section{5- Referências}

\section{Fundos Documentais}

CPI do SAM - Arquivo da Câmara dos Deputados. Coordenação de Comissões Temporárias - Brasília/DF. Periódicos - Acervo da Hemeroteca Digital. Biblioteca Nacional Legislação - Acervo digital da Câmara dos Deputados 
Revista Brasileira de História \& Ciências Sociais - RBHCS

Vol. $12 N^{\circ}$ 24, Julho - Dezembro de 2020

\section{Bibliografia}

CERTEAU, Michel de; MENEZES, Maria de L.; VOGEL, Arno. A escrita da história. Rio de Janeiro: Forense Universitária, 2011.

FALEIROS, Vicente de P. Infância e processo político no Brasil. In: A Arte de Governar Crianças: a história das políticas sociais, da legislação e da assistência a infância no Brasil. Rio de Janeiro (RJ): Editora Universitária Santa Úrsula, 1995.

FAORO, Raymundo; COHN, G. Os donos do poder: formação do patronato político brasileiro. 5. ed ed. São Paulo: Ed. Globo, 2012.

FILHO, Paulo N. Sangue, Corrupção e Vergonha: S.A.M. 1. ed. [s.l.] Empresa Gráfica da Revista dos Tribunais, 1956. v. 1

HOCHMAN, Gilberto. A Era do Saneamento: As bases da política de Saúde Pública no Brasil. [s.l: s.n.].

JUNIOR, Edivaldo G. Movimento Higienista e o Processo Civilizador: $\mathbf{X}$ Simpósio Internacional Processo Civilizador - Unicamp, p. 9, abr. 2007.

LE GOFF, Jacques. História e memória. $7^{\text {a }}$ Edição ed. Campinas - SP: Unicamp, 2013.

LIMA, Augusto S. Relatório do Juizado de Menores do Distrito Federal. Rio de Janeiro (RJ): Imprensa Nacional, 1937.

NETO, DR. Meton de A. Arquivos do Serviço de Assistência a Menores. Distrito Federal - Rio de Janeiro: Ministério da Justiça e Negócios Interiores, jun. 1942.

NUNES, Edson de O. A gramática política do Brasil: clientelismo e insulamento burocrático. Rio de Janeiro: Brasília: J. Zahar Editor; Escola Nacional de Administração Pública, 1997.

PESSOA, GláuciaT. A. Escola Correcional Quinze de Novembro. Arquivo Nacional - MAPA - Memória da Administração Pública Brasileira, maio 2018.

PILOTTI, Francisco. J.; RIZZINI, Irene. A arte de governar crianças: a história das políticas sociais, da legislação e da assistência à infância no Brasil. São Paulo (SP): Cortez, 2009.

RIZZINI, Irene. O século perdido: raízes históricas das políticas públicas para a infância no Brasil. Rio de Janeiro, RJ, Brasil: Cortez Editora, 2008.

RIZZINI, Irene; RIZZINI, Irma A institucionalização de crianças no Brasil: percurso histórico e desafios do presente. Rio de Janeiro, RJ: Brasília, DF: São Paulo, SP: Editora PUC-Rio: CIESPI; UNICEF; Edições Loyola, 2004.

SANGLARD, Gisele P. Entre os salões e o laboratório: filantropia, mecenato e práticas científicas no Rio de Janeiro, 1920-1940. Rio de Janeiro (RJ): Fundação Oswaldo Cruz, 2005. 
Revista Brasileira de História \& Ciências Sociais - RBHCS

Vol. $12 N^{\circ}$ 24, Julho - Dezembro de 2020

VIANNA, Adriana de R. B. O mal que se adivinha: polícia e menoridade no Rio de Janeiro, 1910-1920. Rio de Janeiro: Ministério da Justiça,

Arquivo Nacional, 1999.

Recebido em Junho de 2020

Aprovado em Setembro de 2020

DOI: https://doi.org/10.14295/rbhcs.v12i24.11608 